\title{
ŠI'IJE I SUNIJE - U PERCEPCIJI PROF. IHSAN ILAHI ZAHIRA $^{2}$
}

\section{Sažetak}

Bilo kakav razgovor o stanju Muhammedovog, s.a.v.s., umeta, njihovoj slabosti, nakon progresa i predvodničke uloge u čovječanstvu koju su toliko godina obnašali, neminovno za sobom povlači raspravu o razjedinjenosti i podjeli koju svi vidimo. Nazaobilazna tačka u toj podjeljenosti na razne frakcije i skupine svakako su ši'ije, sljedbenici Alije, r.a., i njegove porodice. Posebno važna činjenica u tome je da su upravo ši'ije te koje su prve počele podmetati $i$ ubacivati lažne hadise, a još je gore od toga vjerovanje jednog dijela te skupine da je Kur'an, koji je prenešen tevatur predajom, neispravan $i$ nepotpun, kako to oni smatraju. Ovaj rad pokušava osvijetliti tu stranu njihove ideologije u percepciji prof. Ihas Ilahi Zahira, rahimehullah, pakistanskog učenjaka, koji je većinu svojih djela posvetio ovoj problematici $u$ islamskom umetu.

Ključne riječi: ši'ije, sunnije, ashabi, imam, tekijje, Alija, r.a.

\section{Uvod}

Ovaj rad ukratko prolazi kroz faze života najodabranije skupine čovječanstva, a to je skupina ashaba, koju je Allah, dž.š., odabrao da budu društvo najodabranijeg Allahovog stvorenja, Muhammeda, s.a.v.s. Kakav je bio njihov odnos prema Poslaniku, s.a.v.s., za njegovog života, šta i kako su postupili nakon njegove smrti prilikom izbora prvog halife, te šta ih je zadesilo od iskušenja za vrijeme trećeg i četvrtog halife, što je rezultiralo pojavom podijeljenosti, jednih kojih su podržavali Aliju, r.a., i onih drugih, koji su imali drukčije mišljenje.

\footnotetext{
${ }^{1}$ Islamski pedagoški fakultet u Bihaću

${ }^{2}$ Ovaj rad odražava stavove prof. Ihsan Ilahi Zahira, rahimehullah, a odnosi se na najradikalnije skupine ši'ija, a ne stavove priređivača ovog rada ili Islamskog pedagoškog fakulteta u Bihaću. Također se nadamo da su stavovi današnjih ši'ija mnogo bliži sunnijama $\mathrm{i}$ da će se $\mathrm{i}$ oni sami ograditi od onih koji ih u svijetu pogrešno predstavljaju. Nadam se da je zajednički cilj svih nas zbližavanje i jedinstvo, a ne razjedinjavanje islamskog ummeta.
} 
Cilj ovog rada nije produbljivati razdor $i$ podijeljenost $u$ islamskom ummetu, nego pobliže upoznavanje sa ši'ijskom ideologijom, koja je svakodnevno na svjetskoj sceni. Koliko god se iskrivljenost njihovog vjerovanja pokušavala zataškati i njihovo uporno opetovanje i ponavljanje parole da „Nema nikakve razlike između ši'ija i sunnija“, posljednja dešavanja u Londonu i drugim gradovima to jasno pobijaju. Javne tribine od strane Jasira El-Habiba i njemu sličnih, koji svojim nastupima javno i bez imalo sustezanja blate i napadaju našu majku Aišu, r.a., njenog oca Ebu-Bekra i većinu ostalih ashaba, stavlja nam u obavezu da bar donekle upoznamo muslimane sa ši'ijskom ideologijom. Evo samo jednog citata od onoga što je na ovoj „svečanosti“ rečeno: "Prisjećamo se uništenja Allahovog neprijatelja i neprijatelja ehlul-bejta, predvodnice žena u Džehennemu čiji je zločin potvrđen iznad sedam nebesa, Aiše, EbuBekrove kćerke, Allah ih prokleo oboje. Nisam u mogućnosti, kao ni drugi, da pobrojim sve zločine ove nevaljalice."

Nemamo ništa protiv jedinstva islamskog ummeta i tome težimo, ali također, imamo obavezu da ukažemo na nedolično ponašanje svakog onog ko na bilo koji način sumnja u Kur'an, širi smutnju i podstiče netrpeljivost među Muhammedovim sljedbenicima.

Ono što je iznešeno u ovom radu je uglavnom percepcija profesora Ihsan Ilahi Zahira, rahimehullah, u njegovoj knjizi „Ěššije' ves-sunne".

Molimo Allah, dž.š., da nam istinu prikaže takvom i pomogne nam da je slijedimo, a da nam neistinu prikaže u njenom pravom obliku i da nas od nje udalji.

\section{ŠI'IJE I SUNIJE}

Hvala Allahu, dž.š., od Kojeg uputu tražimo i neka je salavat i selam na Njegovog posljednjeg i najodabranijeg poslanika, Muhammeda, s.a.v.s., njegovu časnu porodicu, njegove ashabe, među kojima su četverica najodabranijih hulefaurašidina Ebu-Bekr, Omer, Osman i Alija, r.a., i sve one koji slijede njegov put sve do Sudnjeg dana. 


\section{MEĐULJUDSKI ODNOSI KOD ASHABA, R.A.}

Za života Allahovog Poslanika, s.a.v.s., ashabi nisu imali ni tračak sumnje $\mathrm{u}$ obaveznost slijeđenja njegovog puta $\mathrm{i}$ potpunog ubjeđenja da je on poslan svim ljudima. Također su smatrali svojom obavezom da prenose njegovu poruku svim ljudima i generacijama koje će doći poslije njih. Pouzdano nam je prenešeno da ashabi, r.a., za vrijeme Poslanikovog, s.a.v.s., života nisu jedni prema drugima osjećali nikakvu netrpeljivost, sumnju ili pak neprijateljstvo, nego su bili prava braća, koja su se međusobno voljela i uvažavala. Zbližavala ih je ista vjera, zajednički ciljevi, ljubav prema istom Poslaniku, jednoj Knjizi i jednom vjerozakonu. To potvrđuje i kur'anski ajet $u$ kojem Allah, dž.š., o njima kaže:

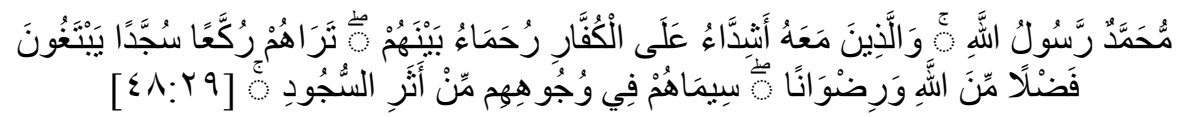

„Muhammed je Allahov poslanik, a njegovi sljedbenici su strogi prema nevjernicima, a samilosni među sobom; vidiš ih kako se klanjaju i licem na tle padaju želeći Allahovu nagradu i zadovoljstvo, na licima su im znaci, tragovi od padanja licem na sedždu. “3

A za Ensarije posebno Allah, dž.š., kaže:

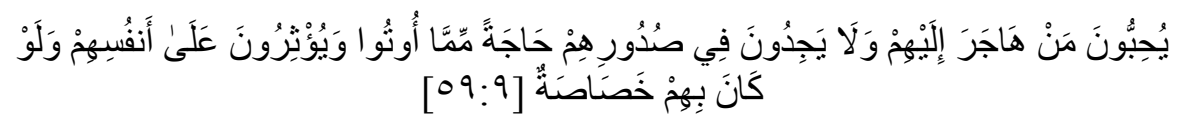

„Oni vole one koji im se doseljavaju i u grudima svojim nikakvu tegobu, zato što im se daje, ne osjećaju, i više vole njima nego sebi, mada im je i samima potrebno." ${ }^{\text {4 }}$

Ashabi su bili primjer međusobne ljubavi, uzajamnog potpomaganja i voljeli su drugima dati više nego samima sebi. Ako bi nekada došlo do nesporazuma i razilaženja u mišljenjima, oni bi se brzo vratili Istini, čim bi je iznašli, a pri tome su bili vrlo korektni, saosjećajni, poštovali su i uvažavali jedni druge. Nisu jedni druge lašcima smatrali, niti su jedni u druge sumnjali. Poštovali su i davali prednost onima koji su islam prihvatili prije njih i bili su zahvalni onima koji su žrtvovali mnogo svog imetka za dobrobit islama. Jedni drugima nisu zavidjeli na onome što je Allah nekom od njih dao od

\footnotetext{
${ }^{3}$ Sura El-Feth, 29.

${ }^{4}$ Sura El-Hašr, 9.
} 
prednosti i vrlina. Zajedničko dobro u kojem su svi uživali bilo je to da su svi ashabi i prijatelji plemenitog Poslanika, s.a.v.s., pozivali ispravnoj vjeri i bili su presretni što ih je Allah, dž.š., spasio od zablude i izveo ih na Pravi put.

\section{SITUACIJA NAKON POSLANIKOVE, S.A.V.S., SMRTI}

Međutim, kada je Allahov Poslanik, s.a.v.s., preselio na bolji svijet, došlo je do prve nedoumice i razlaza, oko toga ko će preuzeti hilafet. Bez obzira što se radilo o vrlo važnoj stvari, a to je vodstvo države, $\mathrm{i}$ to je problem oko kojeg se mnoge skupine i narodi obično posvađaju, oni su o tom problemu dostojanstveno i uljudno razgovarali, iznosili svoja mišljenja i stavove, sve dok nisu došli do rješenja sa kojim su se svi složili. Bilo je pravo čudo kako su oni lijepo razgovarali, kontrolisali se kada govore, poštujući i uvažavajući svakog, a zajednički cilj im je bilo doći do najboljeg rješenja i takav jedinstven primjer ne možemo naći $u$ današnjim izborima $i$ parlamentima. Još je to bilo vrijeme kada u narodu nije bilo poznato savjetodavno tijelo (šura), niti su ljudi imali pravo izbora svoga predvodnika, niti ministra. Pouzdana historija nam prenosi događaj kada su se Ensarije sakupile u Sekifi Benu Saide, nakon Poslanikove, s.a.v.s., smrti, kako bi između sebe izabrali predvodnika muslimana i njegovog nasljednika. Nakon toga dolaze njihova braća, najodabraniji Muhadžiri na čelu sa Ebu-Bekrom, Omerom i Ebu-Ubejdom, koji su s poštovanjem i uvažavanjem saslušali njihova mišljenja i argumente. Zatim je govorio Ebu-Bekr, r.a., i iznosio mišljenje Muhadžira po ovom pitanju, priznajući ulogu i pomoć koju su pružile Ensarije Allahovom Poslaniku, s.a.v.s., i dobrodošlicu koju su im ukazali prilikom njihovog dolaska u Medinu. Nakon toga je Ebu-Bekr podsjetio na vrijednost Muhadžira, bez pretjerivanja i uveličavanja i podsjetio da će Arapi najlakše prihvatiti da halifa bude iz Kurejša, jer ako bude iz medinskog plemena Evs, zamjerit će Hazredžije, a ako bude iz plemena Hazredž zamjerit će pripadnici plemena Evs. Ensarije su odustale i od svog prijedloga da bude jedan predstavnik od Ensarija, a jedan od Muhadžira. Muhadžiri su im tada rekli da bi to bio početak slabosti i nestabilnosti. Zatim je Ebu-Bekr, r.a., predložio prisutnima da izaberu Omera, r.a., ili Ebu-Ubejdu, r.a., za halifu. Tada Omer reče Ebu-Bekru: -Ti si bolji i preči od mene. Ebu-Bekr mu odgovori: -Ali si ti jači od mene. Zatim Omer reče: -Moja snaga će 
biti uz tvoju dobrotu i prišao je i dao mu prisegu (bej'at) na vjernost. Zatim su svi Muhadžiri prišli i dali prisegu Ebu-Bekru. Nakon toga su Ensarije također požurile da daju prisegu Ebu-Bekru, i umalo da pri tome nisu učepili Se'ada ibn Ubadu, koji je bio njihov kandidat za halifu. Tako se stvar na ovom sastanku završila sa konsenzusom na izboru Ebu-Bekra za halifu. Nakon toga su mu prisegu učinili svi ostali. Izostao je Alija, r.a., i nekoliko ljudi (jer su bili zauzeti oko opremanja Allahovog Poslanika, s.a.v.s.,), te su i oni nakon malo vremena dali bej'at Ebu-Bekru.

Tako se završio izbor Ebu-Bekra za prvog halifu, i privela se ova opasna stvar kraju bez ijedne kapi krv, i bez ikakvih zamjerki ili razilaženja. Kada čitaš o ovim događajima, imaš kompletnu sliku o odgoju i moralnom ponašanju ovih ljudi, njihovoj otvorenosti, čvrstini njihove zajednice, snazi njihove međusobne povezanosti i pravog bratstva.

\section{POČETAK FITNE / ISKUŠENJA I NESPORAZUMA}

Tako je potrajalo za vrijeme Ebu-Bekra, Omera i prvom dijelu Osmanovog, r.a., hilafeta. Međusobno su se pomagali, uzajamno savjetovali, razilazili se u nekim stvarima, ali ih to nije ometalo da prihvate istinu i pravo rješenje u svim nesporazumima i da se njoj priklone, bez obzira na privatne stavove. Opći interes im je uvijek bio bitniji od pojedinačnog. Tako su, zajednički potpomažući se, svi učestvovali u izgradnji svoje nove, mlade države, kao iskreni graditelji. Zajednica u kojoj nije bilo neposlušnosti, niti oholosti.

Tako je potrajalo sve do početka iskušenja i problema (fitneta), koji su počeli pred kraj Osmanovog, r.a., hilafeta.

Allahovi neprijatelji, židovi, munafici i drugi stranci su se uvukli među muslimane, prikazujući se da su prihvatili islam, počeli su rovariti i unostiti razdor $u$ tu zajednicu, što je ubrzo rezultiralo ubistvom trećeg halife Osmana, r.a, a zatim i četvrtog Alije, r.a.

Nakon što je Muavija preuzeo hilafet, zli jezici su počeli svašta govoriti o ovoj odabranoj skupini ashaba, prikrivajući se pri tome ljubavlju i privrženošću Aliji, r.a. (tešejju'). Time su željeli nanijeti štetu islamu i osvetiti se onima koji su svojom krvi i svojim životima udarili temelje novoj vjeri, koja se proširila na sve strane svijeta. 
Kao što su ši'ije izrazile svoju privrženost Aliji, r.a., tako su Haridžije nakon „tahkima“/ presude, izrazile svoj stav prema ashabima, smatrajući većinu ashaba koji su tada bili prisutni kafirima, zato što su se, po njihovom mišljenju, usprotivili Allahovoj odredbi, a ko se usprotivi Allahovoj odredbi taj je kafir.

Većina priznate uleme (džumhur) je zauzela pravedan i ispravan stav prema razlazu ashaba i oni su smatrali da su prva trojica halifa bili bitniji za hilafet od Alije, r.a., i smatrali su da je on bitniji od Muavije, r.a. Međutim, oni su podržavali trojicu halifa prije Alije, zatim priznajući pravo Aliji, a zatim Muaviji, oni su imali vrlo korektan i pošten stav prema svim ashabima. Onima koji su možda pogriješili u ovim događajima iznalazili su razlog i prelazili preko njihovih pogrešaka, obzirom da su oni bili mudžtehidi u tom poslu, a mudžtehid nije grešan kada pogriješi, dok god mu je Istina cilj.

Ovo su ashabi, ljudi koji su služeći i šireći islam propatili mnogo toga štiteći Poslanika, s.a.v.s., i njegovu vjeru. Oni su se družili sa Poslanikom, naučili od njega način lijepog ponašanja i zbog svega onoga što su prije ovih iskušenja i smutnji doprinijeli za dobrobit islama, mi smo dužni da ih uvažavamo i smatramo da su oni svi namjeravali učiniti dobro. Trudili su se onoliko koliko su mogli, želeći stići do Istine, pa ko je od njih u tome svemu išao u susret Istini, on ima dvostruku nagradu, a ko je promašio on ima jednu nagradu, kao što je to najavio Allahov Poslanik, s.a.v.s., u hadisu koji glasi: „Kada sudac donosi presudu i pri tome se potrudi, pa ako pogodi pravu presudu, onda ima duplu nagradu, a ako trudeći se presudi pogrešno, onda ima samo jednu nagradu. “5

Da se ovaj nesporazum i razlaz desio među ovim poznatim ashabima i njima sličnim tabi'inima, oni bi ga riješili onako kako su i druge probleme rješavali, na lijep način i uz uzajamno poštivanje i uvažavanje, propagirajući i težeći pri tome da se dođe do Istine. Međutim, ovdje su se sa njima pomiješali i uzeli učešća neprijatelji islama, prikazujući se pri tome kao muslimani, kao i mnogobrojne druge muslimanske skupine, koje su uzele učešća u ovim sukobima. Takvo stanje i situacija je pridodala i pripisala ovoj časnoj skupini ashaba da su oni jedni o drugima govorili ono što nije tačno i što nije

${ }^{5}$ Hadis su zabilježili Buharija i Muslim a naveo ga je i Šafija u knjizi El-Umm, $7 / 252$. 
njihov nivo, niti način međusobnog komuniciranja. Na žalost, takve lažne priče i vijesti su našle utočište u ušima većine ši'ija, tako da su oni bili prvi koji su počeli lagati na ashabe, r.a., i izmišljati lažne (mevdu') hadise u kojima su hvalili Aliju, r.a. To potvrđuju mnogi učenjaci iz ove oblasti, poput Ibn-Ebi El-Hadida komentatora knjige „Nehdžul-belaga“" koji kaže: „Znaj da je početak laganja u hadisima koji govore o vrijednostima i prednostima pojedinaca, došao od strane ši'ija...a nakon toga su im neznalice do sunnija uzvratile istom mjerom. “6

HARIDŽIJE smatraju sve ashabe pouzdanim, ali prije ovih iskušenja i smutnji, a nakon te fitne oni smatraju Aliju, Osmana $\mathrm{i}$ učesnike Bitke oko deve i one koji su prihvatili presudu / tahkim kafirima. Zbog toga su Haridžije odbile sve hadise koje ashabi prenose poslije fitne...

\section{STAV ŠI'IJA PREMA ASHABIMA, R.A.}

Što se pak tiče većine ši'ija, prvenstveno mislimo na one koji su muslimani, oni kritikuju ashabe i ružno se izražavaju o Ebu-Bekru, Omeru, Osmanu i onima koji se s njma slažu od ostalih ashaba. Također se na njihovom udaru nalaze Aiša, Talha, Zubejr, Muavija, Amr ibn El-As i ostali koji su bili umiješani u ,preotimanje hilafeta“ od Alije. Bolje rečeno, oni ne priznaju nikog od ashaba, osim malobrojne skupine koji su bili privrženi Aliji, r.a. Pojedinci spominju cifru od samo 15 ashaba koje oni priznaju. ${ }^{7}$

Drugi pak priznaju samo trojicu ashaba.

Jedan od ši'ijskih učenjaka El-Kešši prenosi od Ebu-Dže'fera da je rekao: „Ljudi su nakon Poslanika postali odmetnici, osim njih trojice: Mikdad ibn Esved, Ebu-Zerr El-Gifari i Selman El-Farisi. “6

$\mathrm{Na}$ osnovu ovoga su postavili svoj mezheb u kojem ne prihvataju hadise nijednog ashaba, osim pod uslovom da se prenose putem njihovih imama koje smatraju nepogrešivim, ili njima sličnim.

\footnotetext{
${ }^{6}$ Komentar Nehdžul-belaga, 2/134.

${ }^{7}$ Dr. Mustafa Siba'i, Es-Sunne ve mekanetuha fit-tešri'ilislami, str. 131.

8 Ridžalul-Kešši, str. 12 i 13. Pogledaj „Eš-Šije'a ves-Sunne“ str. 49, Ihsan Ilahi Zahir.
} 
Njihovo pravilo glasi: Onaj ko nije podržao Aliju, taj je iznevjerio Poslanikovu oporuku (vasijet) i usprotivio se imamima Istine i kao takav ne može biti od povjerenja, niti se na njega može oslanjati.

Većini ši'ija u ovom stavu se protive. ZEJDIJE, koji smatraju da je Alija bolji od Ebu- Bekra i Omera, ali oni priznaju ispravnost njihovog hilafeta i njihove vrline i ovo je najispravnija skupina ši'ija i njihov fikh je vrlo blizu fikhu sunnija.

\section{STAV SUNNIJA O ASHABIMA, R.A.}

Većina (džumhur) muslimana smatra sve ashabe pouzdanim ljudima, bilo to prije ili poslije nesporazuma i sukoba koji su zadesili islamski ummet, bez obzira na kojoj strani je taj ashab bio u tim događajima. Oni prihvataju sve hadise koje prenose pouzdani prenosioci od ashaba, osim ako se radi o sljedbenicima Alije, r.a., od njih se prima samo ono što je došlo putem učenika Abdullaha ibn Mes'uda, r.a., jer su oni bili pouzdani i povjerljivi prenosioci i nisu dozvoljavali laganje na Aliju, r.a., niti bilo koga drugog, kao što je to bilo sa skupinom rafidija.

\section{STAV ŠI'IJA O HADISIMA}

Kao rezultat ovog nekorektnog mišljenja o ashabima došlo je do oštrih napada od strane ši'ija na hadise koje su sakupili i brižno čuvali muslimanski učenjaci, precizno ih obradivši i ocijenivši, i to od vremena ashaba, pa sve do vremena sabiranja hadisa u hadiske zbirke. Ši'ije su ove pouzdane hadise proglasile lažnim i podmetnutim (mevdu), a posebno su napadali i kritikovali hadise koji govore o vrijednostima i prednostima ashaba, koji su inače bili meta njihovih napada. Ši'ije ne prihvataju hadise koje prenose sunnije, osim ako se ti hadisi slažu sa onim što prenose njihovi „bezgrešni imami“. Zbog toga vidimo da su ši'ije, za hadise koji su najpouzdaniji kod sunnija, rekli da su lažni.

Primjer za to je hadis koji je zabilježio Buharija u svom Sahihu, u kojem stoji: „Allahov Poslanik, s.a.v.s., je naredio da se zatvore sva

\footnotetext{
${ }^{9}$ Dr. Mustafa Siba'i, Es-Sunne ve mekanetuha fit-tešri'ilislami, str. 131.
} 
sporedna vrata iz ensarijskih kuća, koja vode u džamiju osim EbuBekrovih vrata." Taj hadis je kod svih priznatih hadiskih učenjaka ispunio sve uvjete sahih i pouzdanog hadisa i u njegovu ispravnost nema nikakve sumnje.

Ši'ije, međutim, smatraju da je ovaj hadis lažan, a nasuprot njemu navode hadis koji oni proglašavaju ispravnim, u kojem stoji: „Allahov Poslanik, s.a.v.s., je naredio da se zatvore sva vrata osim Alijinih, r.a., vrata." i tome slično.

Također ši'ije smatraju da ima hadis u kojem je Poslanik, s.a.v.s., ovesijetio (oporučio) Aliju kao svog nasljednika, i taj hadis uzimaju kao jedan od temelja svoga vjerovanja i njime pravdaju napade i neprijateljstvo koje gaje prema prvoj trojici halifa.

Pozdani hadiski učenjaci kažu da je to lažan hadis i da nema nikakve osnove. Neprihvatljivo je da se svi ashabi urote protiv Alije, r.a., i da se svi dogovore da (pri)kriju takav hadis u kojem je Poslanik ostavio vesijjet/oporuku Aliji. Si'ije čak smatraju da je to bilo javno, pred ashabima. Pa zar da se o ashabima, koje smo ranije opisali, tako nešto ružno i pomisli? Zar da o Poslanikovim, s.a.v.s., drugovima kažemo da su oni bili varalice i lažovi i da prikrivaju istinu?

U svakom slučaju, ovakav neopravdan ši'ijski stav o ashabima i o hadisima je rezultirao mnogim razilaženjem u fikhiskim propisima, što je otvorilo vrata mnogim drugim neprijateljima islama (poput orijentalista i drugih) da siju smutnju i sumnju u sunnet kao drugi šerijatski izvor. ${ }^{10}$

\section{ULOGA ŽIDOVA U SPLETKAMA I RAZILAŽENJIMA}

Jedan broj učenjaka smatra da su Židovi imali veliko učešće u širenju smutnje i razdora među muslimanima, pa su također iskoristili i ovaj moment, kako bi kroz djelovanje pojedinih ši'ija širili svoje neprijateljstvo prema islamu i muslimanima.

Poznati jemenski Židov, iz San'e, Abdullah ibn Sebe', IbnSevda' se posebno u tome isticao. On je prividno primio islam kako bi kasnije mogao da rovari i pravi spletke muslimanima. On je obilazio

\footnotetext{
${ }^{10}$ Pogledaj: Es-Sunne ve mekanetuha fit-tešri'ilislami, str. 132-133, Dr. Mustafa Siba'i.
} 
muslimanske gradove $\mathrm{i}$ države praveći smutnju, još u vrijeme prvih halifa. $^{11}$

\section{MIŠLJENJE ŠI'IJA O KUR'ANU}

Tekstovi koji ukazuju na stav ši'ija o Kur'anu.

Poznati ši'ijski muhadis El-Kulejni, koji slovi kao Buharija kod muslimana, u svojoj knjizi „El-Kafi fil-usul“ prenosi od Hišama ibn Salima, od Ebu-Abdullaha, a.s., da je rekao: „Zaista Kur'an sa kojim je došao Džibril, a.s., Muhammedu, s.a.v.s., ima 17000 ajeta. “12

Po ovom njihovom mišljenju, to bi značilo da su izgubljene dvije trećine Kur'ana.

\section{NEKE ŠI'IJSKE KNJIGE}

Ši'ije smatraju da kod sebe imaju slijedeće knjige:

- Sahifa, u kojoj su spomenuta imena svih ši'ija sve do Sudnjeg dana...

- El-Džami'u, čija je dužina 70 podlaktica, koja je izdiktirana Muhammedu, a napisao ju je Alija, r.a., svojom desnicom, u njoj je svaki halal i haram i sve što je ljudima potrebno, pa čak krvarina $\mathrm{i}$ nadoknada za ogrebotinu...

- El-Džifr, a to je kožna torba u kojoj je ilum znanje Poslanika i onih kojima je ostavljen vesijjet (oporuka), ilum ranijih učenjaka od Benu Israilćana...

- Fatimin Mushaf, koji je veći od našeg Kur'ana tri puta, a u njemu od našeg Kur'ana nema nijednog slova, kako to oni smatraju. ${ }^{13}$

\section{GDJE SE NALAZI TAJ NJIHOV MUSHAF}

$\mathrm{Na}$ pitanje gdje je taj Mushaf koji je Allah, dž.š., objavio Muhammedu, s.a.v.s, a od njega ga je sakupio i naučio napamet Alija

\footnotetext{
${ }^{11}$ Pogledaj:,,Eš-Šije'a ves-Sunne“ Ihsan Ilahi Zahir, str. 29.

12 El-Kafi fil-usul, Kitabu fadlil-Kur'an, babun-nevadir, str. 634. Pogledaj: Ihsan Ilahi Zahir, „Eš-Šije'a ves-Sunne“ str. 80.

13 El-Kafi fil-usul, Kitabul-hudže, bab zikri sahife vel-džifr vel-džamia ve mushaf Fatime, str. 240-241, pogledaj Ihsan Ilahi Zahir, „Eš-Šije'a ves-Sunne“ str. 81.
} 
ibn Ebi-Talib? Na to pitanje odgovara ši'ijski hadis koji prenosi ElKulejni od Salima ibn Seleme koji kaže: „Neki čovjek kod EbuAbdullaha proučio nešto iz Kur'ana, ali to nije bilo poput onoga što ljudi uče, pa mu Ebu-Abdullah reče: -Nemoj više tako učiti, nego uči kao što uči ostali svijet, sve dok ne ustane (Kaim, tj. Mehdi) onaj koji treba ustati, a kada on dođe, on će učiti Allahovu knjigu onako kako treba. Zatim je pokazao Mushaf koji je napisao Alija, a.s. Nakon toga on reče: -Ovaj Mushaf je Alija pokazao ljudima kada je završio sa njegovim pisanjem i rekao im je: -Ovo je Allahova knjiga onakva kakvu je Allah objavio Muhammedu, s.a.v.s., ja sam je sakupio iz dvije levhe. Oni rekoše: -Pa evo mi imamo mushaf u kojem je Kur'an, ne treba nam taj mushaf. On im tada reče: -Tako mi Allaha, vi ga više nikada nećete vidjeti, ja sam bio zadužen da vas obavijestim o tome da sam završio sa njegovim pisanjem pa da ga čitate." ${ }^{\text {14 }}$

Zbog ovoga ši'ije vjeruju da je njihov Mehdija, kojeg očekuju ušao u sirdab (podzemna prostorija) i da će tamo ostati, a sa sobom je uzeo taj Mushaf $\mathrm{i}$ on će ga, kada izađe, sa sobom donijeti. To potvrđuje jedan od ši'ijskih šejhova Ebu-Mensur Ahmed ibn Ebi-Talib Et-Tibrisi (588. po H) u svojoj knjizi „El-Ihtidžadž ala ehlilledžadž“، On kaže: Kada Mehdi izađe sa sobom će nositi Poslanikovo oružje, njegovu sablju Zul-fikar, Sahifu sa imenima ši'ija sve do Sudjeg dana, El-Džimi'u, veliku i malu El-Džifru i Fatimin mushaf.“15

\section{PRIMJERI ŠI'IJSKOG ISKRIVLJIVANJA KUR'ANA}

Muhammed ibn Ja'kub El-Kulejni prenosi od Džabira od EbuDže'fera, a.s., da ga je on upitao: „Zašto je Alija ibn Ebi-Talib nazvan emirul-mu'minin? On reče: -Allah ga je tako nazvao jer je u Svojoj Knjizi objavio:

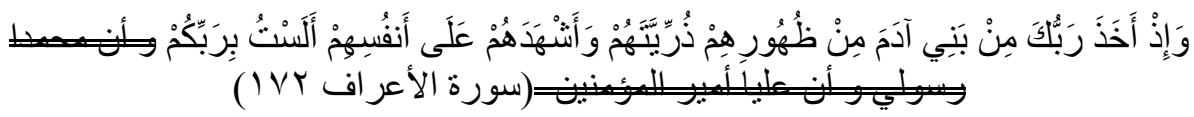

„I kad je Gospodar tvoj iz kičmi Ademovih sinova izveo potomstvo njihovo i zatražio od njih da posvjedoče protiv sebe: -Zar

\footnotetext{
${ }^{14}$ El-Kafi fil-usul, str. 633, pogledaj Ihsan Ilahi Zahir, „Eš-Šije'a ves-Sunne“ str. 89.

${ }^{15}$ Pogledaj Ihsan Ilahi Zahir, „Eš-Šije'a ves-Sunne“ str. 89.
} 
Ja nisam Gospodar vaš? ${ }^{16} \underline{I}$ da je Muhammed Moj poslanik i da je Alija emirul-mu'minin? ${ }^{17}$

Također prenosi od Džabira da je rekao: „Džibril, a.s., je dostavio Muhammedu ovaj ajet:

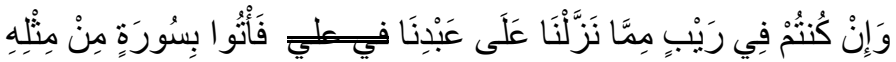

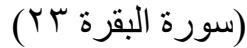

„A ako sumnjate u ono što objavljujemo robu Svome, o_Aliji, načinite vi jednu suru sličnu objavljenim njemu. “18

Prenosi se od Ebu-Besira, od Ebu-Abdullaha, a.s., da je za ovaj iskrivljeni ajet:



„Neko je zatražio da se kazna izvrši, nad nevjernicima u Alijinu vladavinu (vilajet), niko ne može spriječiti, “19 ${ }^{\prime 19}$ rekao: „Tako mi Allaha ovako ga je Džibril dostavio Muhammedu, s.a.v.s.“"20

Prenosi se od Ebu-Hamze, od Ebu-Dža'fera, a.s., koji kaže: „Džibril je ovako dostavio ovaj ajet:

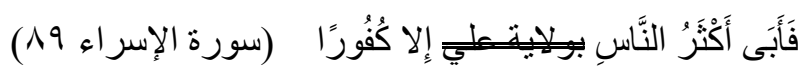

,....ali većina ljudi nikako neće da vjeruje u Alijin vilajet. ${ }^{\text {‘21 }}$

On je također rekao: „Džibril je ovako dostavio ovaj ajet:

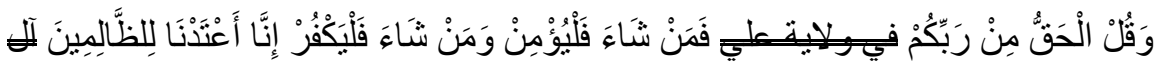

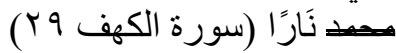

\footnotetext{
${ }^{16}$ Ovdje se završava kur'anski ajet iz sure El-E'araf, 172, a ovo što je iza toga nije Kur'an.

${ }^{17}$ Kitabul-hudže minel-Kafi, babun-nevadir, 1/412. Pogledaj Ihsan Ilahi Zahir, „EšŠije'a ves-Sunne" str. 103.

${ }^{18}$ Ovo što nije podvučeno je dio kur'anskog ajeta iz sure El-Bekare, 23, a ovo ostalo nije Kur'an. Kitabul-hudže minel-Kafi, 1/417. Pogledaj Ihsan Ilahi Zahir, „Eš-Šije'a ves-Sunne" str. 104.

${ }^{19}$ Ovo što nije podvučeno su ajeti iz sure El-Mearidž, 1-2, a ovo ostalo nije Kur'an.

${ }^{20}$ Kitabul-hudže minel-Kafi, 1/422. Pogledaj: Ihsan Ilahi Zahir, „Eš-Šije'a vesSunne" str. 104.

${ }^{21}$ Ovo što nije podvučeno je dio kur'anskog ajeta iz sure El-Isra', 89, a ovo ostalo nije Kur'an.
} 
„I reci: Istina o Alijinom vilajetu dolazi od Gospodra vašeg, pa ko hoće neka vjeruje, a ko hoće neka ne vjeruje! Mi smo nevjernicima u Muhammedovoj porodici pripremili vatru. “'22

Prenosi se od Džabira, od Ebu-Dž'afera, a.s., da je rekao:

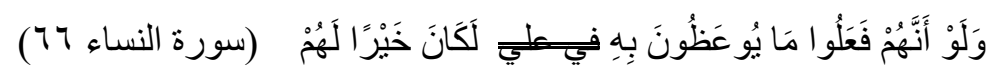

„Ovaj ajet je ovako objavljen: „A kad bi oni onako kako im se savjetuje $\underline{u}$ vezi Alije, postupali, bilo bi im bolje....23

Prenosi se od Džabira, od Ebu-Dž'afera, a.s., da je rekao: „Ovaj ajet je Džibril, a.s., dostavio Muhammedu, s.a.v.s, ovako:

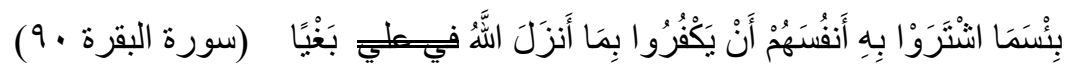

„Jadno je to za što su se prodali; da ne vjeruju u ono što Allah objavljuje o Aliji, samo iz zlobe...“24

Alija ibn Ibrahim El-Kummi u predgovoru svog tefsira prenosi da je Ebu-Abdullah, a.s., rekao: „Ovaj ajet je ovako objavljen:

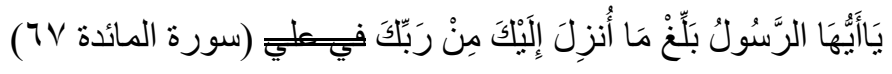

„O Poslaniče, kazuj ono što ti se objavljuje od Gospodara tvoga vezano za Aliju. “25

El-Kulejni prenosi od Husejna ibn Mijaha, od nekog čovjeka koji ga je obavijestio da je neki čovjek u prisustvu Ebu-Abdullaha proučio ovaj kur'anski ajet:



\footnotetext{
${ }^{22}$ Ovo što nije podvučeno je dio kur'anskog ajeta iz sure El-Kehf, 29, a ovo ostalo nije Kur'an. Kitabul-hudže minel-Kafi, 1/422. Pogledaj Ihsan Ilahi Zahir, „Eš-Šije'a ves-Sunne“"str. 104.

${ }^{23}$ Ovo što nije podvučeno je dio kur'anskog ajeta iz sure En-Nisa', 66, a ovo ostalo nije Kur'an. Kitabul-hudže minel-Kafi, 1/424. Pogledaj Ihsan Ilahi Zahir, „Eš-Šije'a ves-Sunne“" str. 104.

${ }^{24}$ Ovo što nije podvučeno je dio kur'anskog ajeta iz sure El-Bekare, 90, a ovo ostalo nije Kur'an. Kitabul-hudže minel-Kafi, 1/262. Pogledaj Ihsan Ilahi Zahir, „Eš-Šije'a ves-Sunne“" str. 105.

${ }^{25}$ Ovo što nije podvučeno je dio kur'anskog ajeta iz sure El-Maide, 67, a ovo ostalo nije Kur'an. Tefsir od El-Kummija, predgovor autora 1/10. Pogledaj Ihsan Ilahi Zahir, „Eš-Šije'a ves-Sunne“" str. 105.
} 
„I reci: -Trudite se! Allah će trud vaš vidjeti, a i Poslanik Njegov i vjernici... ${ }^{\text {26 }}$ Tada mu on reče: -Nije tako, nego trebaš reći:

$$
\text { وَأْمأمونُونَ }
$$

„vel-me'munun“ (pouzdani, povjerljivi) umjesto „mu'minun“ i mi smo „me'munun“ (pouzdani, povjerljivi). ${ }^{27}$

Također El-Kulejni prenosi od Ebu-Dža'fera, a.s., da je rekao: „Džibril, a.s., je ovako dostavio ovaj ajet:

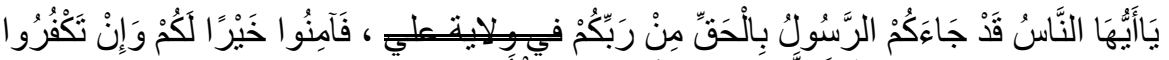

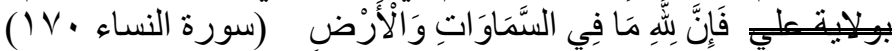

„O ljudi, Poslanik vam je već donio Istinu o vilajetu (vladavini) Alije od Gospodara vašeg; zato vjerujte - bolje vam je! A ako ne budete vjerovali, u Alijin vilajet, pa, Allahovo je ono što je na nebesima i na Zemlji.

Ima još dosta predaja koje govore o Alijinom vilajetu (vlasti) u njihovim hadiskim i tefsirskim knjigama, a što se tiče visajeta, ili vesijjeta (tj. da je Alija preporučen za vlast i hilafet) prenosi ElKulejni od Mualle, koji pripisuje tu izreku Poslaniku, da kur'anski ajet, iz sure Er-Rahman, glasi ovako:

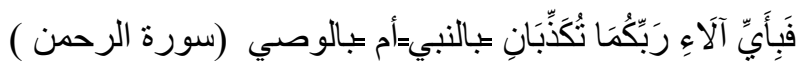

„Pa, koju blagodat Gospodara svoga poričete?!, ${ }^{29}$ Poslanika ili Vesijja (tj. Aliju).“

\section{DRUGE SURE U KUR'ANU}

Mulla Muhammed Bakir El-Medžlisi, jedan od njihovih posljednjih mudžtehida, u svojoj knjizi kaže: „Zaista je Allah u

\footnotetext{
${ }^{26}$ Ovo je kur'anski ajet iz sure Et-Tebve, 105.

27 Kitabul-hudže minel-Kafi, 1/424. Pogledaj Ihsan Ilahi Zahir, „Eš-Šije'a vesSunne"str. 106.

${ }^{28}$ Ovo što nije podvučeno je dio kur'anskog ajeta iz sure En-Nisa', 170, a ovo što je podvučeno nije Kur'an. Kitabul-hudže minel-Kafi, 1/424. Pogledaj Ihsan Ilahi Zahir, „Eš-Šije'a ves-Sunne“" str. 106.

${ }^{29}$ Ovdje se završava kur'anski ajet iz sure Er-Rahman, 16. a ovo što je iza toga nije Kur'an. El-Kafi fil-usul, bab ennen-ni'met elleti zekerehel-Kur'an, 1/217. Pogledaj Ihsan Ilahi Zahir, „Eš-Šije'a ves-Sunne“ str. 106.
} 
Kur'anu objavio suru En-Nurejn (Dva svjetla) i evo njenog teksta...(str. 137)، ${ }^{430}$

Ši'ijski učenjak Mirza En-Nuri Et-Tibrisi je napisao posebnu knjigu „Faslul-hitab fi isbati kitab rabbil-alemin,“ gdje govori o iskrivljenosti Kur'ana. On smatra da Kur'anu nedostaju sura El-Hikd, sura El-Hal' i sura El-Vilaje.“31

Postoje i druge ši'ijske knjige u kojima oni govore o iskrivljenosti Kur'ana. str. (148)

\section{CILJEVI ŠI'IJSKOG ISKRIVLJIVANJA KUR'ANA}

Mnogo je ciljeva ši'ijskog iskrivljivanja Kur'ana, a spomenut ćemo samo neke:

- Ši'ije na ovaj način žele da utvrde princip imameta i vilajeta, koji je glavni temelj njihove vjere, kao što je Er-Rida u svojoj hutbi rekao: „Imamet je osnov islama i njegova najvažnija grana. Namaz, zekat, post $\mathrm{i}$ hadž su kompletni $\mathrm{i}$ ispravani samo sa imamom.“32

Ovo utvrđivanje principa imameta i vilajeta se ne može postići samo ako se iskrivi kur'anski tekst i tako se pokuša utemeljiti njihovo iskrivljeno vjerovanje.

- Oni također, žele zanijekati vrijednost i prednost ashaba, r.a., obzirom da ima mnogo kur'anskih ajeta koji govore o vrijednosti ashaba.

Pogledaj ove ajete, sura: Et-Tevbe, 100, El-Enfal, 74, El-Hadid, 10, El-E'araf, 157, El-Feth, 10, 18, 29, El-Hašr, 8 i 9 i mnogo drugih ajeta koji govore o vrijednostima ashaba, r.a.

U suri Et-Tevbe, ajet 40. govori se o zajedničkom boravku EbuBekra, r.a., i Poslanika, s.a.v.s., u pećini Sevr.

\footnotetext{
${ }^{30}$ Ovu suru je Hatib Bagdadi prenio iz ši'ijske knjige „Dibistanu mezahib“ . Dakle ovu suru Kur'anu pripisuje također i Mulla Muhsin El-Kešmiri. Pogledaj Ihsan Ilahi Zahir, „Eš-Šije'a ves-Sunne“" str. 137.

${ }^{31}$ Faslul-hitab fi isbati kitab rabbil-alemin, str 33. Pogledaj Ihsan Ilahi Zahir, „EšŠije'a ves-Sunne“" str. 139.

${ }^{32}$ Kitabul-hudže minel-Kafi, babun-nevadir 1/200. Pogledaj Ihsan Ilahi Zahir, „EšŠije'a ves-Sunne“ str. 107.
} 
- Njihovo nepriznavanje ashaba rezultira osporavanjem i pobijanjem ispravnosti i autentičnosti Kur'ana, čije sakupljanje u mushaf se odvijalo u vrijeme prve trojice hulefa'ur-rašidina.

\section{ZAŠTO NEKI ŠI'IJSKI UČENJACI NE SMATRAJU KUR'AN ISKRIVLJENIM}

Pojedini učenjaci ši'ija su se javno izjasnili da je Kur'an neizmijenjen i da u njemu nema nikakvog nedostatka, niti viška. Od njih je Muhammed ibn Alija ibn Babevejh El-Kummi, kod njih zvani Es-Saduk, umro 381. h. god. autor knjige: „Men la jahduruhul-fekih“. On je prvi od ši'ija u tom vremenu koji je rekao da je Kur'an ispravan $\mathrm{i}$ da u njemu nema nikakvih izmjena.

Ihsan Ilahi Zahir ${ }^{33}$ to objašnjava ovako: $\mathrm{S}$ obzirom da ima mnogo pouzdanih predaja - po njihovom mišljenju - kod ši'ija da je Kur'an iskrivljen i da u njemu neke sure nedostaju, kao što je u njemu dodano nešto što njemu ne pripada $i$ da je jedini ispravni Kur'an onaj koji je kod njihovog Mehdije kojeg očekuju... U 4. stoljeću po H. se rodio Muhammed ibn Alija ibn Babevejh El-Kummi, koji je uvidio da ljudi mrze i ne podnose ši'ije zbog takvog njihovog mišljenja o Kur'anu, obzirom da oni smatraju da je Poslanik rekao: „Ostavio sam vam dva sekalejna (dvije vrlo važne i skupocjene stvari), pa ako se njih budete držali nećete nikako zalutati, Kur'an i moja porodica (ehlul-bejt),“ pa ako budu ovako negativno govorili o Kur'anu, kako onda da ga se pridržavaju. A ako se ne budu pridržavali ove prve i važnije stvari, kako će onda poštovati drugu spomenutu stvar, a to je njegova porodica.

Kada je ovaj ši'ijski učenjak uvidio ovu stvar, onda se priklonio slijedećem mišljenju, koje glasi: „Mi smo uvjerenja da je Kur'an ono što je Allah objavio Muhammedu, s.a.v.s., i to je ono što se nalazi sakupljeno u mushafu koji se nalazi kod muslimana, u njemu ništa ne fali..." (sve dok nije i ovo rekao): „Ko za nas kaže da mi o Kur'anu nešto drugo, mimo ovog spomenutog kažemo, taj je lažac. ${ }^{\text {(34 }}$

\footnotetext{
${ }^{33}$ Pogledaj: Ihsan Ilahi Zahir, „Eš-Šije'a ves-Sunne“ str. 124-125.

34 „El-I'tikadat“ od Ibn-Babevejha El-Kummija, babul-e'akad fi meblegil-Kur'an, štampano u Teheranu 1224. h.g. Pogledaj: Ihsan Ilahi Zahir, „Eš-Šije'a ves-Sunne““ str. 126.
} 
Za ovim njegovim mišljenjem se poveo i Sejjid El-Murteda, zvani Ilmul-huda, umro 436. god. po H., kao što je to od njega prenio ši'ijski mufessir Ebu-Alija Et-Tibrisi.

Njih dvojicu, u ovom stavu, je slijedio Ebu-Dž'afer Et-Tusi, umro 460. god. po H., koji u svom tefsiru „El-Bejan“ kaže: „Mišljenje da u Kur'anu nešto fali ili da je višak je neosnovano i ne dolikuje da se tako nešto o Kur'anu kaže.، ‘35

I četvrti ši'ijski učenjak koji je zastupao ovo mišljenje bio je ši'ijski mufessir Ebu-Alija Et-Tibrisi, umro 548. god. po H. kao što je to iznio u svom tefsiru „Medžme'ul-bejan“.

Međutim, sva četverica ovih učenjaka u svojim drugim knjigama navode predaje koje ukazuju na iskrivljenost Kur'ana.

Mnogo je ši'ijskih knjiga koje govore o iskrivljenosti Kur'ana. Ihsan Ilahi Zahir je spomenuo u svojoj knjizi „Eš-Šije'a ves-sunne“. (str. 147-150).

Ovo su jedina četverica ši'ijskih učenjaka koji su rekli da u Kur'anu nema iskrivljivanja, a Ihsan Ilahi Zahir smatra da su i oni zastupali takav stav samo da bi se izbjegle kritike i netrpeljivost ostalih muslimana prema ši'ijama. A sve to se opet temelji na principu tekijje (tajenje, opreznost, prikrivanje vjerske pripadnosti kod ši'ija) i munafikluka, koji se smatra jednim od stubova njihove vjere.

\section{PRINCIP TEKIJJE تقية KOD ŠI'IJA}

Ši'ije smatraju da je تقية tekijje (tajenje, opreznost, prikrivanje vjerske pripadnosti kod ši'ija) jedan od temelja njihove vjere, a to je iznošenje neistine, odnosno laži, kako bi zaštitili interese svoje vjere i to smatraju dozvoljenim, pa čak i obaveznim principom u njihovom ophođenju sa ljudima.

Oni su ovu običnu obojali bojom svetosti, pa su joj dali naziv: tekijje, a to bi moglo značiti, zaštita, opreznost prikrivanje vjerske pripadnosti i tome slično.

${ }^{35}$ Et-Tibjan, 1/3, štampan u Nedžefu. Pogledaj Ihsan Ilahi Zahir, „Eš-Šije'a vesSunne" str. 126. 
Njihov učenjak Muhammed ibn J'akub El-Kulejni, koji kod njih slovi poput Buharije kod nas, prenosi da je Ebu-Dža'fer (peti imam kod njih) rekao: „Tekijje je od moje vjere i vjere mojih predaka, jer ko nema tekijje taj nema ni vjere.636

Ibn-Babevejh El-Kummi u svojoj poslanici „El-I'tikadat“ kaže: „Tekijje je vadžib (obaveza) pa ko je ostavi, taj kao da je napustio namaz..." (pa je onda rekao:)

„Tekijje je vadžib (obaveza) i nije je dozvoljeno napuštati sve dok ne dođe Mehdi, a ko je napusti prije toga taj je izišao iz vjere Uzvišenog Allaha i iz vjere imama, i taj se usprotivio Allahu, Poslaniku i imamima.“

Es-Sadik, a.s., je upitan o značenju kur'anskog ajeta:

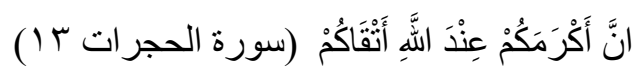

„Najpriznatiji kod Allaha su oni ko su najbogobojazniji,“ pa je rekao: „To znači: oni koji najviše prakticiraju tekijju. ${ }^{\text {(37 }}$

Njihov najpoznatiji muhaddis Muhammed ibn J'akub El-Kulejni, prenosi da je Ebu-Omera El-E'adžemija, da mu je Ebu-Abdullah, a.s., rekao: „O Ebu-Omere, Devet desetina vjere je u tekijji i ko nema tekijje taj nema ni vjere. ${ }^{\text {‘38 }}$

Ši'ije pojašnjavaju zašto su uzeli princip tekijje u svom vjerovanju, ali su se po tom pitanju razišli, kao što su se razišli i po drugim pitanjima:

Jedna skupina ši'ija smatra da je tekijja vadžib (obavezna) u čuvanju života, časti i imetka.“

Njihov šejh Et-Tusi u svom tefsiru Et-Tibjan kaže: „Tekijja je vadžib u strahu za život, ali je dozvoljeno govoriti i istinu.“

Druga skupina kaže da je tekijja vadžib, bilo da se radi o zaštiti života ili nečeg drugog. El-Kulejni prenosi od Zurare, od Ebu-

\footnotetext{
${ }^{36}$ El-Kafi fil-usul, babut-tekijje, 2/219. Pogledaj Ihsan Ilahi Zahir, „Eš-Šije'a vesSunne" str.153.

37 „El-I'tikadat“ od Ibn-Babevejha El-Kummija, babut-tekijje, štampano u Teheranu 1274. h.g. Pogledaj Ihsan Ilahi Zahir, „Ěs-Šije'a ves-Sunne“ str. 126.

${ }^{38}$ El-Kafi fil-usul, babut-tekijje, 2/217. Pogledaj Ihsan Ilahi Zahir, „Eš-Šije'a vesSunne" str.154.
} 
Dža'fera, a.s., da je rekao: „Tekijja se koristi u svakoj nuždi, a sam čovjek najbolje zna kada je ta nužda (darura).“

Treća skupina kaže da je tekijja dozvoljena kada se brani život. Ši'ijski mufessir Et-Tibrisi u komentaru ajeta „Illa en tetteku minhum tuka'“ kaže: „U ovom ajetu imamo dokaz da je tekijja dozvoljena u vjeri kada strahujemo za svoj život.“39

Njihov najpoznatiji muhaddis Muhammed ibn J'akub El-Kulejni, prenosi od Ebu-Omera El-E'adžemija, da mu je Ebu-Abdullah, a.s., rekao: „O Ebu-Omere, devet desetina vjere je u tekijji i ko nema tekijje taj nema ni vjere. ${ }^{640}$

Ši'ije prenose od svog prvog, nepogrešivog imama Alije ibn Ebi Taliba da je rekao: „Tekijja je od najboljih djela vjernika, jer on pomoću nje štiti sebe i svoju braću od neprijatelja.““41

Od svog trećeg imama Husejna ibn Alije prenose da je rekao: „Da nema tekijje ne bi se mogao raspoznati naš prijatelj od našeg neprijatelja. “42 Kao da je laž najbolji način raspoznavanja istine kod ši'ija.

Njihov peti imam Muhammed ibn Alija ibn Husejn, poznat kao El-Bakir, kaže: „Meni nema ništa draže od tekijje, jer je tekijja štit vjernika." ${ }^{43}$

Njihov osmi imam Alija ibn Musa kaže: „Nema vjere onaj koji nema takvaluka, nema vjere onaj koji nema tekijje. Najbogobojazniji od vas je onaj koji najviše primjenjuje tekijju. Oni mu rekoše: $\mathrm{O}$ sine (nasljedniče) Allahovog Poslanika, do kada tako trebamo postupati? On im reče: Sve do određenog roka, a to je dan kada će se

\footnotetext{
${ }^{39}$ Medžme'ul-bejan, tefsir ajeta: „Illa en tetteku minhum tuka'“ Pogledaj Ihsan Ilahi Zahir, „Eš-Šije'a ves-Sunne“ str. 180.

${ }^{40}$ El-Kafi fil-usul, babut-tekijje, 2/217. Pogledaj Ihsan Ilahi Zahir, „Eš-Šije'a vesSunne“"str.154.

41 Tefsir od Askerija, str. 162. Pogledaj Ihsan Ilahi Zahir, „Eš-Šije'a ves-Sunne“ str. 157.

${ }^{42}$ Tefsir od Askerija, str. 162. Pogledaj Ihsan Ilahi Zahir, „Eš-Šije'a ves-Sunne“ str. 157.

${ }^{43}$ El-Kafi fil-usul, babut-tekijje, 2/220. Pogledaj Ihsan Ilahi Zahir, „Eš-Šije'a vesSunne“"str.158.
} 
pojaviti naš Mehdi, jer ko napusti tekijju prije njegovog dolaska taj ne pripada nama." 44

To, ustvari, nije ništa drugo do prikrivanje istine i ispoljavanje laži. Da bi svoje pogrešno vjerovanje osnažili, izmislili su hadis kojeg prenose od Sulejmana ibn Halida da mu je Ebu-Abdullaha rekao: „O Sulejmane, vi slijedite takvu vjeru, ko je bude prikrivao Allah će ga ojačati, a ko tu vjeru bude obznanio Allah će ga poniziti. ${ }^{* 45}$

\section{SUNIJSKI STAV PO OVOM PITANJU}

Ovo je ši'ijsko vjerovanje i njihov stav o laganju koje oni previše uvažavaju i smatraju ga principom svoje vjere.

Kako prihvatiti ovo njihovo mišljenje, pored kur'anskog ajeta $\mathrm{u}$ kojem Allah, dž.š., kaže: „O Poslaniče, dostavi ono što ti se objavljuje od tvoga Gospodara, jer ako to ne uradiš nisi dostavio poslanicu. " 46

Allah, dž.š., također kaže: „Javno obznani ono što ti se naređuje i prođi se mušrika. “47

Poslanik, s.a.v.s., u hutbi na Oprosnom hadžu pojašnjava principe svoje vjere, javno je obznanjuje i na kraju pita: „Jesam li vam dostavio? Oni odgovaraju: -Jesi. Zatim Poslanik kaže: „Allahu moj, posvjedoči mi to! Neka prisutni prenese ovu poruku onome ko je odsutan i mnogo je onih kojima bude prenešeno, pa oni to bolje razumiju nego oni koji su to izravno čuli. “48

U drugom hadisu Poslanik, s.a.v.s., kaže: „Allah se smilovao čovjeku koji čuje nešto (od ove vjere) pa to prenese onako kako je čuo, a mnogo je onih kojima bude prenešeno pa oni to bolje razumiju nego oni koji su to izravno čuli. “49

\footnotetext{
${ }^{44}$ Kešful-gimme od Irdiblija, str. 341. Pogledaj Ihsan Ilahi Zahir, „Eš-Šije'a vesSunne“"str.161.

${ }^{45}$ El-Kafi fil-usul, babut-tekijje, 2/222. Pogledaj Ihsan Ilahi Zahir, „Eš-Šije'a vesSunne" str.154.

${ }^{46}$ Sura El-Maide, 67.

${ }^{47}$ Sura El-Hidžr, 94.

${ }^{48}$ Muttefekun alejhi.

${ }^{49}$ Hadis je zabilježio Tirmizi.
} 
Poslanik u mnogo hadisa podstiče da se vjera od njega prenosi drugima i da se javno iznosi. Poslanik kaže: „Prenesite od mene pa makar samo jedan ajet! ${ }^{650}$

\section{Zaključak}

Nakon djelimičnog iznošenja stavova i mišljenja pakistanskog učenjaka Ihsan Ilahi Zahira, možemo zaključiti slijedeće. Iskreni sljedbenici Muhammeda, s.a.v.s., koji se nadaju susretu s njim na Sudnjem danu, njegovom šefa'atu i da ih Poslanik, s.a.v.s., pozna kao svoje prave sljedbenike, imaju jasno postavljenje kriterije i pravila kojih se trebaju pridržavati. Besprijekorno vjerovanje i slijeđenje svega što je u Kur'anu, a.š., poštovanje i uvažavanje ashaba, r.a., kao prve i najodabranije generacije Muhammedovih, s.a.v.s., sljedbenika, poštivanje kriterija koje su pouzdani učenjaci hadisa postavili kao regulativu prihvatanja predaja, te slaganje sa onim na što se usaglasila većina učenjaka (džumhur), osnovne su postavke kojih treba da se pridržava svako onaj ko želi da bude iskreni pripadnik islamskog ummeta. Svako izbjegavanje i zaobilaženje ovih kriterija, bez obzira na način opravdavanja takvih stavova, dovodi njenog počinioca $u$ nezavidan položaj, koji mu ne garantuje spas i blagostanje na onom svijetu. Sumnjati u ispravnost Kur'ana, pa čak ijednog njegovog harfa je vrlo opasna i teška zabluda. Princip tekijje (tajenja isnine) kod ši'ija je vrlo zabrinjavajući i o tome bi se moglo posebno pisati.

Ljubav prem svim ashabima, među kojima su i ehlul-bejt je sastavni dio našeg vjerovanja. U jednom hadisu Poslanik, s.a.v.s., kaže: „Nemojte psovati, grditi ili pak kritikovati moje ashabe, jer tako mi Allaha, kada bi neko od vas udijelio koliko je brdo Uhud zlata, ne bi dostigao stepen i deredžu koju su oni dostizali dijeleći pregršt ili pola pregršti datula."

Ono što se od nesporazuma desilo među ashabima, mi za to nećemo biti pitani, niti smo zaduženi da se oko toga raspravljamo i da oko toga presuđujemo. U jednom drugom hadisu Poslanik, s.a.v.s., kaže: „Kada se spomenu moji ashabi, suzdržite se (od nepotrebnih komentara i presuđivanja)!‘

\footnotetext{
${ }^{50}$ Hadis je zabilježio Buharija.
} 
Lijepo bi i korektno bilo da se od stavova koje javno iznose pojedini smutljivci koji se pripisuju ši'ijama ogradi ostala ši'ijska ulema, kako bi na taj način umanjili jaz koji postoji između njih i sunnija i time učinili bar jedan korak ka objedinjavanju i približavanju oprečnih stavova.

Allahu naš, uputi nas Pravom putu i objedini naša srca na Istini!

\section{Literatura:}

1. Kur'an s prevodom, Besim Korkut, Medina, 1412.h.g.

2. Ihsan Ilahi Zahir, Eš-šije'a ves-sunne, 23. izdanje, Lahor 1984.

3. Ihsan Ilahi Zahir, Eš-šije'a vet-tešejju', 10. izdanje, Darus-selam, Rijad, 1995.

4. Mustafa Es-Siba'i, Es-sunne ve mekanetuha fit-tešri'ilislami... 
Fuad Sedic, Ph D

\section{SHIA AND SUNNI MUSLIMS - IN THE PERCEPTION OF PROF. IHSAN ILAHI ZAHIR}

\section{SUMMARY}

Any conversation about the state of Muhammad's, peace be upon him, Ummah, their weakness after the progress and the leading role in humanity which they held for so many years, inevitably entails a discussion on its disunity which we all see.

Unavoidable point in the divisions of Muslims into the various factions and groups are certainly the Shia Muslims, which are the followers of Ali and his family. Particularly important is the fact that they were the first who started to forge and spread the false Hadiths. Even worse than that is the belief of one part of the Shia that the Qur'an is defective and incomplete,although the Qur'an has been narrated with the method of Tawatur. This paper attempts to illuminate at least to some extent this side of their ideology in the perception of prof. Ihsan Ilahi Zahir, a former Pakistani scholar, who has devoted most of his works to this issue in the Islamic community.

Keywords: Shia, Sunni, Companions of the Allah's Messenger, Imam, takijje, Ali 
الأستاذ الدكتور فؤاد سيديتش

\section{الشيعة والسنة في فكر الأستاذ إحسان إلهي ظاهري}

\section{خلاصة البحث}

إن أي كلام عن أمة محمد صلى الله عليه وسلم، عن ضعفها بعد التقدم والدور

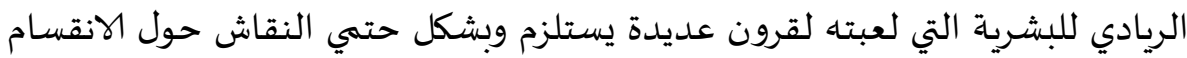

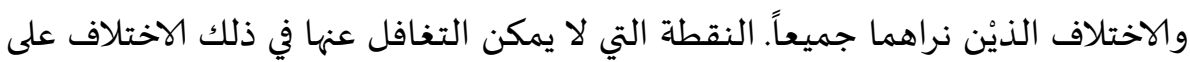
الفئات والجماعات المختلفة هم الشيعة، أصحاب علي رضي الله عنه وآل بيته. الحقيقة

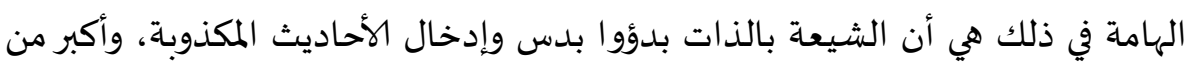

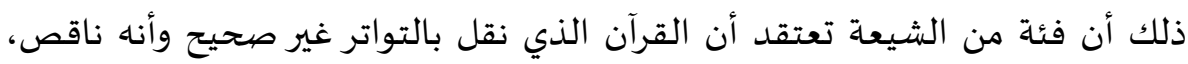
حسب زعمهه.

هذا البحث يحاول ولو إلى حد معين تسليط الضوء على ذلك الجانب من

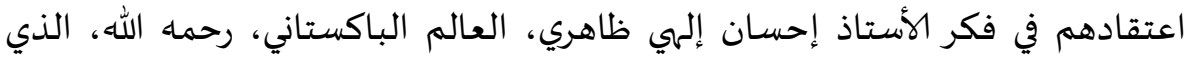

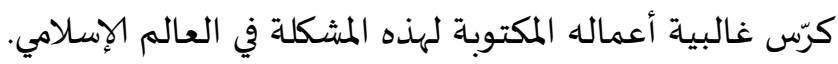


علي رضي الله عنه 